\title{
Materials Purchasing Management Workflow Modeling of Construction Project Based on CPR
}

\author{
Cui Bo \\ State Key Laboratory of Hydraulic Engineering Simulation and Safety, Tianjin University \\ Tianjin, China 300072 \\ cuib@tju.edu.cn
}

\begin{abstract}
Keywords: CPR; engineering construction project; materials purchasing management; workflow modeling

Abstract. With the emerging of Construction Process Reengineering (CPR), the modern engineering construction project management information system should face the whole process of construction process reengineering. Material management is an important job of construction project management, material procurement management, as the sub-process of the general process of the material management, plays an important role in ensuring the smooth material management. This paper takes material procurement management as the research object and applies CPR theory method to conduct the modeling of material procurement management workflow.
\end{abstract}

\section{Introduction}

In recent years, some domestic and foreign scholars apply the workflow technology to realize the support of engineering construction project management information system for management process $[1,2,3]$. With the emergence of Construction Process Reengineering (CPR) theory [4,5], modern engineering construction project management information system has to face the whole process of Construction Process Reengineering not only to implement the results of the process reengineering to support the new operation manner of the project management process, but also put itself in the transformation environment of the process reengineering.

Material procurement management is an important job of construction project management. This paper takes material procurement management as the research object and applies CPR theory method to conduct the modeling of material procurement management workflow.

\section{Analysis on traditional materials purchasing management workflow}

The traditional materials purchasing management process of construction project is shown in Figure 1. According to the purchasing plan, the purchasing department of owner investigates the market, inspects and recognizes relevant materials supply units, and determines the selection scope of materials suppliers. The purchasing department makes enquiry and negotiation with multiple supply units in the selection scope when purchasing, selects the objective supplier and signs the purchasing contract by comparison. Afterwards, the objective supplier delivers goods and materials to construction site.

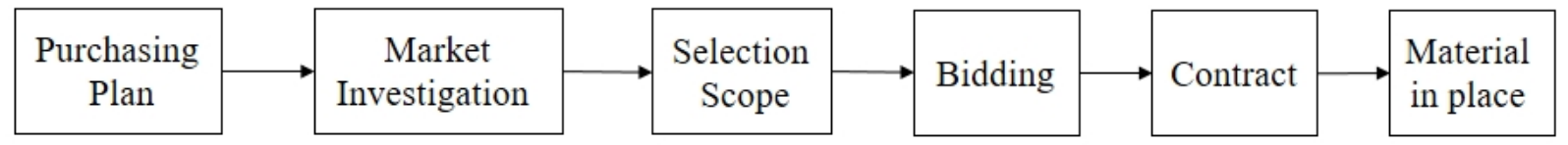

Fig. 1 Traditional materials purchasing management process of construction project

The existing problems in the traditional materials purchasing management are:

(1) The materials with different specifications and varieties are applied with the same purchasing management method and without the difference of primary and secondary. A lot of energies are wasted in the purchasing of ordinary materials, but some important and scarce materials cannot be 
sufficiently noticed, so that the goods cannot be obtained, and the supply is interrupted to influence the engineering progress.

(2) Short of management on supplier. The emphasis of purchasing management is placed on market investigation and price negotiation, so the purchasing department cannot supervise the materials quality provided by supplier, and only conduct quality inspection after arrival of goods. The purchasing department does not establish strategic partnership with materials supplier, so the complex purchasing process, long period and high risk will be caused.

(3) The transparency and sharing of information are poor. The information between purchasing department and other departments of owner is not transparent. The owner is short of information communication with supervisor and construction unit, so he cannot collect the actual construction situation timely and influence the decision.

\section{Optimization of materials purchasing management process}

According to the existing problems, the following optimizing strategies are put forward:

(1) Strengthen the management of suppliers. According to actual demand situation of engineering, the management module of materials supplier should be established to record the detailed quality and price of goods of supplier, contract performance and other indicator data, and divide the grade of supplier accordingly. The purchasing department should select suitable supplier to establish the strategic partnership for purchasing the important materials.

(2) The purchasing department should classify the materials reasonably, and use different purchasing modes. Classify the materials according to the degree of importance, and different type materials use different purchasing modes. For example, bulky and key materials are JIT purchasing and engineering auxiliary materials in quantitative purchasing, and non-key materials are sentinel purchase.

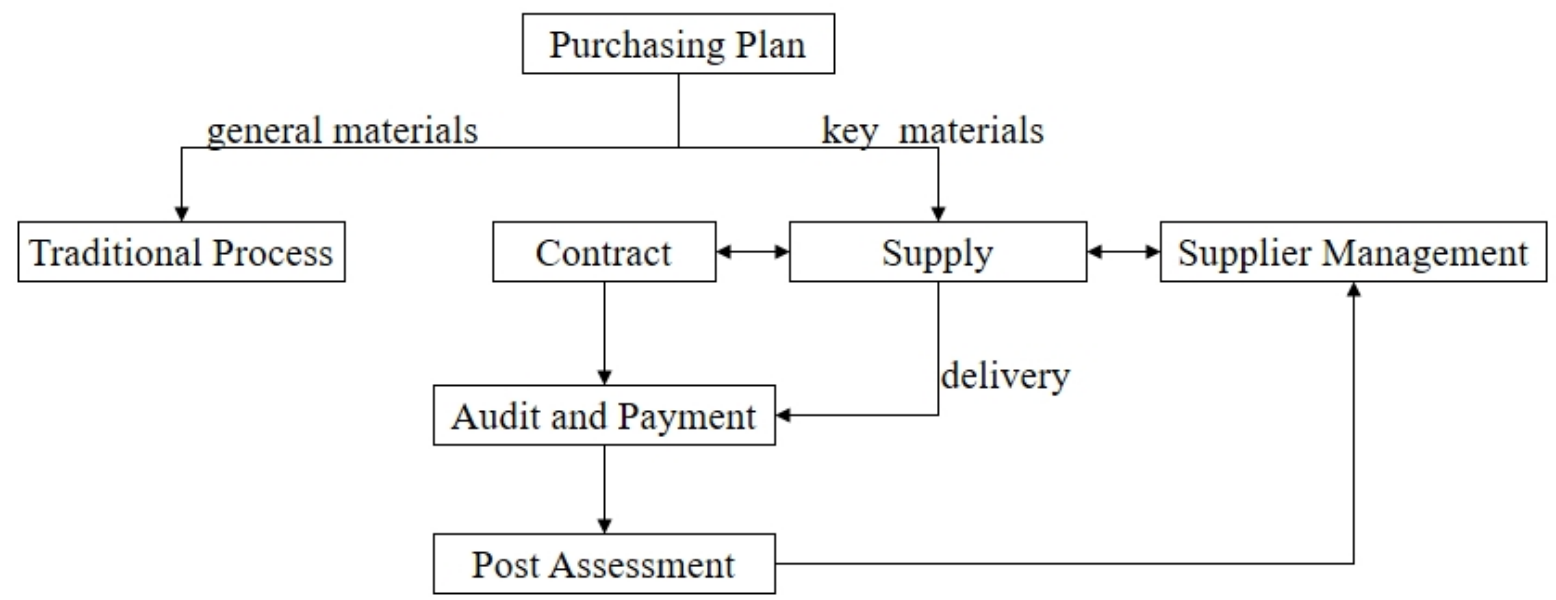

Fig. 2 Optimize materials purchasing management process of construction project

Optimize materials purchasing process based on above optimizing strategy is shown in Figure 2. For general materials, it is still adopted traditional purchasing mode; for key materials, and for important materials, purchase from effective supplier that has established strategic partnership, and conduct supply in engineering supply chain. The optimized purchasing process can simplify purchasing execution process, shorten purchasing cycle and reduce purchasing cost.

\section{Material purchasing management responsibility allocation matrix}

Responsibility allocation matrix is a method and tool that implements decomposed working tasks to related department and person of the project, and clearly represents the relation, responsibility and status of them in the organization. Draw the responsibility allocation matrix aiming at a certain management process, and decompose management activities of the process to determine responsible department of each management activity and in-out contents of each activity in order to satisfy 
informationization requirements, as shown in Table 1. Responsibility allocation matrix is the diagram form reflection of management work and organization integration.

Table 1 Material management responsibility allocation matrix

\begin{tabular}{|c|c|c|c|}
\hline $\begin{array}{l}\text { Management } \\
\text { activity }\end{array}$ & $\begin{array}{l}\text { Responsible } \\
\text { department }\end{array}$ & Input contents & Output contents \\
\hline $\begin{array}{l}\text { Purchasing } \\
\text { plan } \\
\text { formulating }\end{array}$ & $\begin{array}{l}\text { Owner plan } \\
\text { department }\end{array}$ & $\begin{array}{l}\text { Material budget and } \\
\text { declaration form of } \\
\text { the purchase of } \\
\text { material and } \\
\text { equipment, etc. }\end{array}$ & $\begin{array}{l}\text { Bulk building materials, } \\
\text { electromechanical equipment, fire } \\
\text { work materials, office supplies and } \\
\text { purchasing plan of living appliances } \\
\text { are reflected by statement }\end{array}$ \\
\hline $\begin{array}{l}\text { Market } \\
\text { research }\end{array}$ & $\begin{array}{l}\text { The owner } \\
\text { material } \\
\text { department }\end{array}$ & $\begin{array}{l}\text { Type, quantity and } \\
\text { time of planned } \\
\text { purchasing materials }\end{array}$ & $\begin{array}{l}\text { Investigation report of market } \\
\text { deliverability for planned purchasing } \\
\text { materials; Investigation and evaluation } \\
\text { report of materials supplier's } \\
\text { comprehensive strength in reputation, } \\
\text { qualification and scale }\end{array}$ \\
\hline $\begin{array}{l}\text { Purchasing } \\
\text { bidding }\end{array}$ & $\begin{array}{l}\text { The owner } \\
\text { material } \\
\text { department }\end{array}$ & $\begin{array}{l}\text { Investigation report } \\
\text { of material supply } \\
\text { market }\end{array}$ & Materials Purchase Contract \\
\hline $\begin{array}{l}\text { Supplier } \\
\text { management }\end{array}$ & $\begin{array}{l}\text { Engineering } \\
\text { department, } \\
\text { materials } \\
\text { department of the } \\
\text { owner }\end{array}$ & $\begin{array}{l}\text { Post-purchase } \\
\text { evaluation of } \\
\text { materials }\end{array}$ & Supplier rating \\
\hline $\begin{array}{l}\text { Purchasing } \\
\text { surveillance }\end{array}$ & Supervision unit & $\begin{array}{l}\text { Purchase by } \\
\text { construction unit }\end{array}$ & Purchasing surveillance suggestions \\
\hline $\begin{array}{l}\text { Material } \\
\text { quality } \\
\text { management }\end{array}$ & $\begin{array}{l}\text { The owner } \\
\text { material } \\
\text { department }\end{array}$ & $\begin{array}{l}\text { Purchasing } \\
\text { surveillance } \\
\text { suggestions of } \\
\text { supervising unit, } \\
\text { review conclusion of } \\
\text { materials }\end{array}$ & $\begin{array}{l}\text { Materials quality evaluation, materials } \\
\text { in-warehouse management generates } \\
\text { material account }\end{array}$ \\
\hline $\begin{array}{l}\text { Materials } \\
\text { acceptance }\end{array}$ & Construction unit & $\begin{array}{l}\text { Purchase by } \\
\text { construction unit }\end{array}$ & Materials acceptance conclusion \\
\hline $\begin{array}{l}\text { Material } \\
\text { re-inspection }\end{array}$ & Supervision unit & $\begin{array}{l}\text { Acceptance } \\
\text { conclusion of } \\
\text { construction unit }\end{array}$ & Materials review conclusion \\
\hline
\end{tabular}




\section{Modeling of materials purchasing management workflow}

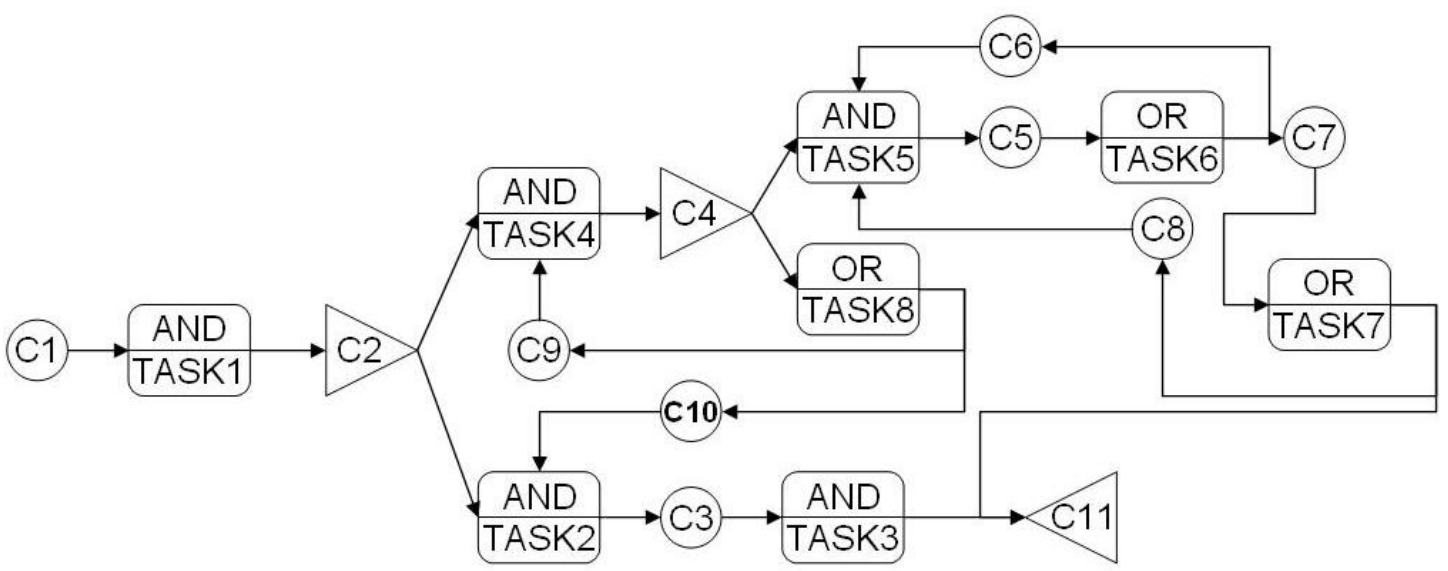

Fig. 3 Materials management workflow model

According to the optimized materials management process and the materials management responsibility allocation matrix, use Petri net method to establish materials management workflow model, as shown in Figure 3. Basic elements of Petri net, as shown in Table 2, are constituted by place and transition, and place represents transfer conditions of status, while transition represents working task place. In the model of workflow Petri net, TASK refers to specific contents of single management activity, and $\mathrm{Ci}$ refers to in-out contents.

Table 2 Materials management workflow Petri net model element paraphrasing

\begin{tabular}{|c|l|c|l|}
\hline Transition & Management activity contents & Place & In-out contents \\
\hline TASK1 & $\begin{array}{l}\text { Material purchasing plan } \\
\text { formulating }\end{array}$ & C1 & $\begin{array}{l}\text { Material budget and declaration form of the } \\
\text { purchase of material and equipment, etc. }\end{array}$ \\
\hline TASK2 & Materials purchasing management & C2 & Material purchasing plan statement \\
\hline TASK3 & Material quality management & C3 & Materials arrival list \\
\hline TASK4 & $\begin{array}{l}\text { Self-purchasing materials } \\
\text { purchasing plan formulating of } \\
\text { construction unit }\end{array}$ & C4 & $\begin{array}{l}\text { Self-purchasing materials purchasing plan } \\
\text { statement of construction unit }\end{array}$ \\
\hline TASK5 & $\begin{array}{l}\text { Self-purchasing materials } \\
\text { purchasing of construction unit }\end{array}$ & C5 & $\begin{array}{l}\text { Self-purchasing materials arrival list of } \\
\text { construction unit }\end{array}$ \\
\hline TASK6 & Materials acceptance & C6 & Unqualified material list \\
\hline TASK7 & Material re-inspection & C7 & Qualified materials list \\
\hline TASK8 & Approved by supervisor & C8 & Unqualified material list \\
\hline & & C9 & Objected by supervisor \\
\hline & & C10 & Confirmation table of supervisor \\
\hline & & C11 & $\begin{array}{l}\text { Materials quality evaluation form, materials } \\
\text { account }\end{array}$ \\
\hline
\end{tabular}

\section{Conclusions}

The paper applies CPR theory method into construction project materials purchasing management workflow modeling, and studies process optimization and integration issue; build responsibility allocation matrix, and use Petri net to build materials purchasing management workflow model based on this. Materials purchasing management as a part of whole construction project management, the application of CPR theory method in materials purchasing management workflow modeling can provide support to whole project management workflow modeling. 


\section{Acknowledgements}

This work is financially supported by the National Natural Science Foundation of China (No. 51209159) (No. 51409188) and the National Basic Research Program of China (973 Program) (No. 2013CB035906).

\section{References}

[1] Fang Yongquan, Wang Xuben. Scientific and Technological Management of Land and Resources, 2002, 4 (13)

[2] Dong-Eun Lee, Jonathan J.Shi. Construction research congress, ASCE, San Diego, USA, 2005.4

[3] Uwe R, Thomas K. Http://e-pub.uni-weimar.de/volltexte/2004/170/pdf/icccbe-x_159.pdf

[4] David Thorpe. Fifth annual conference innovation in construction, Brisbane, Australia, 2000.11

[5] Lu Yong. Infrastructure Optimization, 2005, 3 (3) 